\title{
In Search of Recognition: Gender and Staff-Detainee Relations in a British Immigration Removal Centre ${ }^{1}$
}

Mary Bosworth (University of Oxford and Monash University) and Gavin Slade (University of Toronto)

\begin{abstract}
In this article we draw on research conducted in a British immigration removal centre to explore the affective nature of detention. We consider staff and detainee testimonies of their everyday interactions within the IRC as bids for recognition of social status in an institution characterized by uncertainty and diversity. In their accounts, men and women draw on gendered identities to make sense of others and themselves. Responses to status subordination in the IRC played out across a range of emotional responses, mediated and framed by gender. While these responses emerged in everyday interactions, the frustrations of life in an IRC, we argue, speak to much wider struggles over the status of immigrants in the UK, the confused and contested purpose of IRCs, and the widening of detention as a strategy of migration control; in short, to matters of living under conditions of mass mobility.
\end{abstract}

\section{Keywords}

Recognition; immigration detention; gender; banter; identity

'I arrived here with so many dreams, and now I'm leaving with

nothing.' (Graffiti written in Pashto on one of the cell walls,

Fieldnotes 30 April, 2012).

\footnotetext{
${ }^{1}$ We would like to thank Jamie Bennett, currently governor of HMP Grendon and HMP Springhill who, while centre manager at IRC Morton Hall, originally volunteered the institution as a research site. We would also like to thank Karen Head, the centre manager of IRC Morton Hall during the fieldwork, as well as Alan Kittle, who was then head of the Returns Directorate at UKBA. We greatly appreciate the time of the staff and detainees who participated in the project. In particular, Marie Walker was very supportive and helpful during the fieldwork. The fieldwork was funded by a British Academy Research Development Award, while the writing up for Mary was funded under an European Research Council-Starter Grant, 'Subjectivity and Penal power in a Global world' and for Gavin by a Commonwealth Fellowship of the Department of Foreign Affairs and International Trade of the Government of Canada. The article has been improved by useful comments we received from Jamie Bennett, Emma Kaufman and Sarah Armstrong.
} 
This paper draws on research conducted in one British Immigration Removal Centre (IRC), Morton Hall, as part of a larger study of how people make sense of immigration detention (Bosworth, 2014). Everyday accounts from staff and detainees, we suggest, are usefully understood as bids for recognition of social status (Fraser, 1999; 2007; Honneth, 2006), as men (and a few women among the staff) struggled to cope with their experiences and to find common ground in a 'hyper-diverse' institution in which all members were marked out by varying degrees and kinds of 'status-insecurity'. Recognition concerns competing claims for social status, and is the pre-requisite for social justice (Fraser, 1997; 2000; 2003; 2007). Misrecognition, in these terms, is the social subordination of one individual by another. When misrecognized, individuals of a given group are denied social status. They are excluded and "prevented from participating as a peer in social life [as] a full member of society" (Fraser, 1997: 113).

Whereas academic ${ }^{2}$ scholarship on the prison stresses the importance of relationships between staff and prisoners for maintaining order and securing legitimacy (see, inter alia, Liebling, 2005; Liebling and Price, 2010; Liebling, Arnold and Straub, 2012; Crewe, 2009; Philips, 2012), we know very little about how staff and detainees interact in immigration removal centres. In this paper, we argue that the concept of recognition has considerable explanatory power for understanding lived experience in IRCs. Recognition lies at the heart of people's search for meaning and sense of self, matters that are often under particular

2 And policy. See for example House of Commons Justice Committee, 2009; Braggins and Talbot, 2004. 
pressure in custodial environments where common sources of recognition are difficult to access (Liebling, Arnold and Straub, 2011).

The detainees that populate IRCs are obviously status-insecure, confined and without clear legal standing in the UK. Yet, many claim an equivalent British identity, having lived here for a number of years. Some assert the ties (and legitimating effect) of work, pointing to their employment history and roles as taxpayers, while others appeal to affective bonds, mentioning their British relatives. Still others grapple with the stigmatizing effects of their time in prison, feeling they continue to carry the status of 'criminal' well beyond the end of their sentence (Bosworth, 2012).

Perhaps unexpectedly, staff members are also status-insecure. They work for an austerity-hit prison service, where their job is increasingly vulnerable, in an IRC, where they are no longer technically prison officers. Unlike prisons, where the power of the officers is considerable and can shape prisoners' experiences of custody, the power of the detention custody officer is muted. They do not have the same leverage over detainee behavior and (at least some) feel the erosion of authority keenly. The real decision-makers - the United Kingdom Border Agency (UKBA) case owners - are elsewhere, leaving detention custody officers uncertain both about the purpose and justification of their job and about their status and professional identity.

Citizenship has been a central concern in the struggle for achieving recognition in multicultural societies, (Kymlicka \& Norman 2000). This is the most obvious status claim on the part of detainees - their legal status in the UK. On the part of staff, the most obtruding status claim is to recognition of their professional identity. In interactions, these pressing claims stand out against 
broader identity categories. In IRCs, staff and detainees turn to citizenship, race and gender as well as and other markers of identity in making sense of each other.

This paper focuses on the way gender in particular mediated emotional responses to misrecognition and status subordination. Feminists, from a range of perspectives, have emphasized the salience of gender in terms of recognition (Fraser, 2000; Young, 1990). In the IRC, for some, gender provides a means of challenging their stigmatized identities, for others it is a further barrier to recognition. As we will show, male and female officers must negotiate cultural and professional understandings of gender roles in their interactions with detainees. Detainees may emotionally respond to status-insecurity by asserting their masculinity as the one visible identity left to them, yet their identity may still be questioned by staff, many of whom had previous experience working in women's prisons.

Before exploring such matters, we outline the immigration detention estate and Morton Hall in more detail. We then provide three sections discussing status confusion between staff and detainees; masculinity, female officers and the role of banter; and gender and nostalgia among staff at Morton Hall. In the concluding sections, we tie our discussion into broader themes surrounding state power, immigration and how recognition and misrecognition in IRCs reflect questions of belonging, acceptance and justice in an era of mass mobility. 


\section{IRC Morton Hall and Immigration Detention in the UK}

Currently, 3000 men, women and children are detained under Immigration Act powers in the UK in secure custodial institutions, redolent of penal power. In addition, an unspecified number of foreigners are held under the same powers in police cells, secure hospitals, prisons, and juvenile detention centres. Most IRCs are built to the architectural specifications of high-security prisons or are located in former prisons that have been, in the parlance of the prison service, 're-roled'.

Of the ten IRCs dotted around the country, four are currently contracted out to the prison service. IRC Morton Hall is one of them. Situated in a rural, agricultural area in eastern England, Morton Hall was until early 2012, a lowsecurity women's prison containing a high concentration of foreign national prisoners. Previously, it was an open men's prison. The custodial staff in Morton Hall are, for the most part, white and English, drawn from the local community. Most are men, although a sizable proportion of female officers remain.

At the time of the research Morton Hall had been an IRC for less than one year. According to population records given to us at the time, it held 382 detainees, haling from 52 different countries. Those from the Indian subcontinent predominated, constituting almost half of the total detainee population $(44 \%){ }^{3}$ There were also high numbers of Chinese $(7 \% \mathrm{~N}=28)$ and Jamaicans (5\% N=17), while Afghanis, Iranians, Zimbabweans, Vietnamese and Algerians all made up sizable and recognizable communities. In terms of religion, Muslims made up the single biggest faith group, accounting for nearly half ( $49 \%$

\footnotetext{
${ }^{3}$ Indians made up $17 \%$ of the detainee population $(\mathrm{N}=65) ; 13 \%$ was Bangladeshi $(\mathrm{N}=48) ; 11 \%$ Pakistani $(\mathrm{N}=40)$ and 3\% Sri Lankan (N=11).
} 
$\mathrm{N}=189$ ) of the population. Sikhs and Hindus also comprised substantial religious groups.

Morton Hall stretches over a wide, green space with lawns on the inner compound and trees and fields outside the perimeter fence. There are facilities for football, basketball and tennis as well as a gym. There is a library and a multifaith centre as well as a shop and a computer room in which the men can access the internet, although some websites, such as social networking sites, are blocked. A limited amount of paid work is available. Detainees may seek employment in workshops that, at the time, produced ball bearings, but have in other periods housed industrial sewing machines. They may also apply to work in the kitchen, in the grounds, or as barbers.

Daily life in Morton Hall is punctuated by roll call that occurs three times a day. During this period men must return to their housing units ${ }^{4}$ to be counted. Some units keep cell doors unlocked, allowing detainees to circulate. All wings are closed during the evenings and for roll call. Detainees deemed to be higher risk are locked in their rooms for the night and during roll call. Their rooms have en-suite facilities. All housing units have association rooms for socializing and some are equipped with pool tables and TVs.

After a preliminary visit and meeting with the Senior Management team by Mary Bosworth, Gavin Slade conducted all the fieldwork in Morton Hall. 5 Visiting the IRC every day, Monday to Friday, over a period of one month, he

\footnotetext{
${ }^{4}$ Reflecting its life as a former women's prison, the units in Morton Hall are named after famous British women: [Mary] Seacole, [Elizabeth] Fry, [Queen Elizabeth II] Windsor, [Helen] Sharman and [Amy] Johnson. One further unit, Torr, carries the name of the local aristocratic family who owned the original, long demolished, stately home from which the IRC takes its appellation.

${ }^{5}$ In addition to observation and interviews, the research involved the distribution of a survey on the coping mechanisms and health of detainees as part of a bigger study, the results of which are published elsewhere (see, for example, Bosworth, 2012; Bosworth and Kellezi, 2013; Bosworth, 2014; On Morton Hall in particular, see Bosworth, Kellezi and Slade, 2012).
} 
clocked up 160 hours of participant observation. Over this time he conducted 32 in-depth interviews, most of which (24) were done individually. The remaining eight meetings occurred in small groups, the largest of which included four men. In total 44 detainees consented to be interviewed. Participant information sheets were presented in all cases and verbal or written consent obtained. Most (25 of 32) were recorded. The rest were unrecorded but extensive notes were taken and written up immediately afterwards. All but one multiple-respondent interview was recorded. This unrecorded interview involved only two respondents. Interviews lasted from 20 minutes to two hours.

As well as many informal conversations, Gavin recorded interviews with 12 staff. Eight of these respondents worked inside the inner compound, seven as duty officers on the units and one as a diversity officer in the diversity centre. The remaining four worked in the Welfare unit. One was at management level. Five were men. All had experiences working on units; all had worked at Morton Hall before it became an IRC. Gavin also spent time observing the day-to-day workings of the IRC in the grounds, around the staff offices in the residential units, in the library and diversity centre and the 'Hub' unit that contained computing facilities and the shop.

\section{Status Confusions: Staff-Detainee Relations}

The purpose and justification of IRCs is deeply contested. Whereas the state argues that such places are its right and obligation -- a necessary part of border security, opponents emphasize their damaging effect, their arbitrary nature and their lack of efficiency in managing migration. Far removed from debates 
between policy makers and reformers, both staff and detainees are frequently unclear about the ambit of such places.

Detainees, unsurprisingly, are often bitter about their detention. Though some were aware their immigration status or crime rendered them subject to detention, few anticipated being sent to such an institution. Many arrive directly from having signed on as usual as asylum seekers, while others might have been taken in a raid when the UK Border Agency was looking for someone else. From the staff's perspective, few admit to aspiring to work in an IRC, and many are explicitly critical of them. Most fall into the job due to extraneous circumstances which, in the case of Morton Hall, was because the prison had 're-roled' only a few months before.

There is considerable confusion at the policy level as well as on the ground about the distinction between IRCs and prisons. In those facilities run by the prison service, such confusion is magnified. At Morton Hall, a large number of the detainees are former prisoners who committed offences that carry automatic deportation orders. Detainees generally felt that such men adjusted better to life in the IRC. However, many of them resented being seen as criminals now that their sentence was over.

'Listen, I don't disagree that I did a crime. I accept that. I got sentenced. I went to jail. I did not kick off, did not say any bad words. I ride my sentence... I was doing a course in jail. Everything I completed. I finished my jail sentence. I done all the programmes that they set up for me. Yeah? Boom. I come here now. This is another jail sentence.' (R13) 
There are important differences between IRCs and prison. Although Morton Hall offers some education and employment opportunities, most detainees spend the majority of their days anticipating the outcome of their immigration case. Some resist their removal/deportation, while others pass their time as best they can, awaiting the van to the airport. Nobody knows precisely how long they will be held. Many fight their deportation orders, taking their cases to higher and higher appeal courts. The process is painstaking and time consuming. Meanwhile, their legal status in the UK is suspended. Detainees may have lived in the UK for many years, some since childhood. A number of them have families, including children, who might have been born or naturalized as British citizens.

Denied legal recognition, detainees frequently attempt to assert a status as a kind of equivalent citizen (Bosworth, 2012). Accounts vary depending on their circumstances. For C. from Bangladesh, matters were clear: he belonged in the UK.

'I came as a child [when I was four] with my family, with my parents. I didn't ask to come here... I've got family. I've got kids. I've got parents living here. I've got friends. I grew up here. I went to school. I went to college' (R10).

L., also from Bangladesh, felt he had a strong case. Even the officers thought he was British: 
'[T] he officers, when they hear me talking, they go "L., you sound just like a Cockney lad. What you doing here?" Because I'm from East London innit? So, you know what I mean? Four years and up mate. Sound as a pound. Pint of lager and a packet of crisps. They find it a bit weird as well.' (R15)

L. differentiated between 'British' detainees like himself and others, whom, he averred had less compelling claims. This was a distinction mentioned by some of the other men:

'I don't want to like say I'm different from all the other foreign nationals...But you can see the big difference already, cos they entered this country illegally; I've got indefinite stay here. But I don't go on about it to people and everything because everyone's got their own problem, and you don't want to drive it home to them "Oh you're illegal" because they're another human being, they've got feelings.' (R15)

Many men, however, dismissed such fine divisions. Their status as a detainee was insurmountable, they said, no matter what their previous life in the UK had been like. Before detention, T., originally from Zimbabwe, identified as a parent and a worker, subject positions that were acknowledged in interactions with his children's teachers and his co-workers. In Morton Hall, however, he was simply 'African': 
'You know, because when I'm outside, you take your kids to school, you talk to the teachers. Everything is okay. You're doing your (...) work. You're doing that. Everything is okay. But when you come here, it's all different. It's all different. Ethnic, ethnic group B2. You feel that, "oh my... I'm African. I'm in a foreign land".' (R13)

T.'s interactions with staff reinforced his sense of otherness, he said. Even when they did not explicitly concern his citizenship or ethnicity, he was made to feel subordinate:

I woke up in the morning, went downstairs, came down to the [staff unit] office, said to them, "what's wrong with the heaters? They're broken." This guy just goes, 'you don't deserve heat.'... got food the other day. There is one officer, one female officer that I get along with. She was sitting in the dining room...So I'm saying to her, "it looks good. I hope it tastes good, you know." And [another] officer goes, "does it matter? The food is free." You know? (R13)

The responses of these two members of staff played on a familiar political discourse that stigmatizes and elides 'scroungers,' the unemployed, and foreigners. The message to T. was clear: as a detainee he simply had no right to expect comfortable quarters and decent food, even though such matters constitute the baseline for an adequate (decent) immigration detention system (HMIP, 2012). 
Men in Morton Hall attempt to overcome their status subordination in a number of ways. Many became enraged, yelling at those staff members who put them down and refusing to accept that their detention defined their identity, acting out instead a dominant form of masculinity.

Detainee: 'What are you people doing coming in my room to search it when I'm sleeping?'

Officer: 'We check everybody's rooms - you're not special.'

Detainee: 'What do you mean I'm not special? Maybe I'm not special to you. But to some people I'm special - to my family I'm special. I'm special! Who do you think you're talking to? My family pay their taxes - they pay you! What do you mean I'm not fucking special...who do you think you're fucking talking to?' (Research Notes, 7 May 2012)

Others withdrew and became depressed, opting out of as many interactions as they could. Some questioned the legitimacy of the British state itself, appealing to the protections of the European Convention on Human Rights, or identifying themselves as torture victims.

'Sometimes...I'll get flashback from what happened to my dad and what happened to me...It started when I came to this place...All I think about here is I'm gonna go back to the same thing again...I'd rather be in detention here for life. I prefer that than going back to Gambia.' (R20) 
Still others distinguished themselves as subalterns, inverting questions of culpability and desert: 'They [the British] went around the world stealing everything and they are still stealing from us' (Research Notes, 24 April 2012).

Such attempts to resist subordination and misrecognition were only ever partially successful. For most detainees, the simple objects and architecture of the IRC made their lack of status clear. The fences, barred windows and uniformed staff drive home the point: those without immigration status are unwanted, prisoners despite serving no sentence. Though they tried to challenge their implicit criminalization, their resources were few: 'I belong to very good family.' H. from Pakistan poignantly commented. 'I never handcuffed before. But that's, that the system here.' (R18)

The difficulty many detainees have in setting out a coherent and recognizable identity has implications for the institution as a whole. Interpersonal relations are hard to forge with strangers. Under these circumstances, it is not surprising that staff and detainees rely on familiar tropes of race, class and gender, which intersect with discourses and expectations about citizenship and migration to make sense of one another and themselves.

\section{Banter, Masculinity and the Role of the Female Officer}

Like prisons, immigration detention centres are highly gendered institutions, in which, with some exceptions, ${ }^{6}$ women and men are held separately, in single-sex environments. Sometimes gender can be a resource for detainees, a means by which to assert an alternative identity to that of a 'detainee.' In this vein, as in

\footnotetext{
${ }^{6}$ For example, those IRCs which hold family groups or couples (Tinsley House, the Cedars Uni, and Yarl's Wood), and others which have a small number of women held separately within a male institution (Colnbrook and Dungavel).
} 
prison, a number of the men at Morton Hall spent considerable time working out in the gym, perfecting a muscular male physique. Physical exercise could also help men adapt to their new surroundings and fill their empty days:

'[H]aving been detained before, I immediately set about finding out those things that I knew made me comfortable there, and finding them here - finding a gym so that I would know that I'd be able to train and have something to do when I woke up...' (R32)

Gender relations were sometimes complicated by perceived (and actual) cultural and religious differences. Some variants of Islam and Orthodox Judaism, for instance, prohibit physical contact of any kind with a member of the opposite sex outside the family; believers cannot even shake hands. At other times there are different cultural expectations regarding authority. In a custodial environment, such factors are easily interpreted as questions of obedience and respect, particularly when detainees refused to talk to female officers insisting on male officers instead. British staff understood and managed these cultural differences through gendered expectations of their own.

Soon after it became an IRC, Morton Hall absorbed a number of male officers following the closure of nearby Ashwell men's prison, altering the gender balance of the staff. Despite his lack of experience working in an IRC, one of the new intake explained that he could work more effectively at Morton Hall than his female colleagues who had been there for many years, simply because he was a man. 
"We can banter with the cons they can get on better with us than with female officers. Most of them have no respect for women, in the beginning it wasn't working, you had them saying to you 'I'm not taking orders from some white, honky wide-ass' so it was right to bring in blokes and get us working on the units." (Research Notes, 2 May 2012)

What his view of gender overlooks, however, is the cultural specificity of masculinity. The supposed superior male ability to 'banter' was, in fact, not always good for staff-detainee relations. Detainees were often confused or angered by staff members' jokes. Bantering in a British context involves a masculine performance involving quick-wittedness, which, while having a competitive element, can also establish social closeness and rapport. All too often, for the men who were enduring the deprivations and uncertainty of detention, what the staff viewed as good-natured teasing felt like hostile mockery, yet another refusal to recognize their status claims. '[S]ome people yesterday found little stones in their food', complains one of the reps. 'They were the lucky ones,' S. [officer] says. (Research Notes, 25 April 2012)

Some detainees sought to counter the banter by asserting their own form of masculine dominance. This could be a dangerous strategy.

A Nigerian man I had also talked to previously, with plenty of stored up attitude had come back to the unit after a day in court.

Detainee: 'You need to unlock my door, innit? I've been at bail all day.' Male Officer: 'You can't get in your room?' 
D: 'It's a cell not a room, it's got bars on the windows, what room has that?'

O: 'It's a luxury pad is what it is...."innit".'

D: 'Nah man it's a cell.'

O: 'What's your name again? Here's your room label you have to reattach that by the door. We'll be along in a minute.'

D: 'I ain't doing that [throws down the label]. You do it. That's your job innit? That's what you get paid for [chest out and winks at the officer contemptuously].'

O: 'Right....you....[goes purple with anger]...you don't get it, you need me for a lot longer than I'll need you....'

D: 'No, no, sir, you're alright. I like you. I'll do it.' [picks up the label and walks off] (Research Notes, 1 May 2012)

The potential conflict between these two men arose from the officer's attempt to joke about what the detainee's room should be called and his mimicry of the man's speech patterns. Such jocularity failed to appreciate the detainee's vulnerable emotional state returning from court. In this case, D. simply refused to play along, attempting instead to assert his status by stipulating what the officer's job was, inverting the dominant-submissive roles of the two actors. The officer has little recourse to re-impose authority in such a situation.

Where male officers see sarcasm and wit as tools for establishing relations with detainees, however much they backfire in the multicultural context of the IRC, for women the process of earning recognition and respect from the detainees can be difficult. Some female staff relied on banter to manage 
the men, but as one explicitly stated, they found it more difficult to govern men informally than they had women.

'[C]ertainly we're used to having banter with the women. And you can have banter with the men, but on top of that it's [pauses] not all the men, I wouldn't say it is all the men. You know, some of them are perfectly fine, but others are constantly making comments. Or trying to find out about your personal life, or who you are, are you married, have you got kids? Where do you live?' (RS4)

Although most of the female officers enjoyed working with detainees, all of them complained that (some) detainees made sexually demeaning comments and appeared not to respect them:

"You English whore' is about the worst one anybody's ever called me. And I was so shocked...I have to walk down a landing with twenty men on, and there might be five or six high risk to females and whatever...[so] I do like it when I come to work in the morning and I see this big mountain of a man in uniform. And I think "Yeah, that's what we need, a few more big men" [...] As a new girl on that unit...everybody wanted to try their luck at how far they could push me...it was so frustrating. So I was going home thinking "I can't cope"...after a few weeks I think they realised I wasn't a pushover, and I wasn't just a soft girlie.' (RS11) 
There are no adjudications in removal centres, and while detainees can be segregated for failing to comply with detention centre rules, any such demand has to be agreed by the UKBA onsite staff. Detention custody officers have little autonomous power of their own. Instead, they rely on a range of soft, interpersonal skills such as patience and persuasion to defuse conflicts and convince detainees to obey. Under these circumstances, matters of recognition and the dangers of misrecognition are evident: people need some level of shared understanding in order to get along. Such questions are compounded in an institution where the staff are unsure of their own identity.

\section{'From Utopia to what it is Now': Staff Roles, Nostalgia and Gender}

Staff expressed considerable ambivalence about their role as detention custody officers, 'mourning' 7 their lost status as prison officers. Like the detainees, they were often unable to understand the purpose of the institution and what they were doing there. As one female member of staff, who had initially chosen to go to Morton Hall to work with women, said:

"In terms of being a prison any more, we're not. But we're more like a prison, security-wise, than we ever were. ${ }^{8}$ And then obviously the fighting and the self-harm and things are probably worse than what we were when we were female. But yet the other side of it, we're not." (RS1)

\footnotetext{
${ }^{7}$ This term was put forward by the former manager of Morton Hall, Jamie Bennett.

${ }^{8}$ As an 'open prison', when Morton Hall held female offenders, it had very low security. Upon conversion to an IRC, new fences were constructed, and locks put on doors and windows. Even so, in the first year a number of men escaped.
} 
Without the rationale of punishment or rehabilitation associated with prison, many seemed to be unsure whom exactly they were keeping in custody, their moral standing, and even the necessity of their confinement.

“Q. So do you still see yourself as working in a prison and...

A: Yeah.

Q: ...being a prison officer? You don't see this as...

A: Still wear the uniform. Still doing the same job. It's... At the end of the day, these guys are deemed to be innocent, not committed any crimes, same as civilians. But they're in detention. They're held in a secure environment. I'm a prison officer and that's what I do.... I don't, I don't actually, I don't look at them as criminals, but I don't look at them [pausing] They have committed, they have done wrong, because they're in the country without [pausing] A lot. Not all of them. A lot of them are here because they shouldn't be." (RS5)

This inability to recognize the detainees combined with confusion over the purpose of their job led staff to question themselves, generating considerable levels of ontological insecurity among them. Some responded to this status confusion by relying more heavily on the symbolic articulation of their identity.

'As long as I'm in this uniform, this is a prison officer uniform, with the Queen's thing on and I'm a prison officer, so...And if somebody said to me "You've got to change your uniform, become a custody 
officer" it'd be like "See you then. Going to go find a real prison to work in." At least you know where you are with them.' (RS11)

Others spoke wistfully of their past, when Morton Hall was a prison, and their job made sense.

"Since we, since we re-roled [job satisfaction is] far less than it used to be. Dealing with women was great, because you got the outcomes. You could help. They were receptive to help and guidance. And at the end of it you got thank yous. You know, you really did get a thank you. They used to send you cards saying, 'thank you very much for all your help while I've been here.' that satisfaction of getting to that point was tremendous...Yeah." (RS5)

In this account, the officer clearly missed working with a custodial population who recognized and appreciated her. Their identity reinforced her own. In contrast, the men are not thankful and, in any case, she cannot help them, because she does not understand why they are there. 'But now there's nothing there at all...To be fair, because there's not a lot I can do for them....And they [UKBA]'re a black art to me. I know nothing about them." (RS5)

Others took up the same thread, speaking of 'the golden years ... [when] we had the girls here' (RS3); a time when Morton Hall was 'a utopia sort of thing' (RS1). This wistfulness, longing for a community of women, reveals the gendered nature of recognition, in which our interpretations of others and our capacity to understand them reflects, at least in part, fundamental ideas about 
women and men. Given the local of history of Morton Hall, such matters were particularly evident, as the detainees were frequently compered to the previous female occupants. For some staff, the male detainees were feminized and even more needy than women.

'[I]t was strange for us when I saw them cry in front of us, I didn't know what to do. Because, you know, we weren't trained for that, we trained more like, you know, 'boys don't cry.'”' (Research Notes, 30 April 2012)

Yet while the men were needy 'like women' they did not have women's needs. As a result, their demands felt less legitimate and were, in any case, not the type of requests that staff could accommodate.

'Women would come to you and say "Miss, can you arrange an emergency phone call? I haven't spoken to me kids for four weeks, and I'm really missing them" and whatever. And you'd arrange that, you'd try to help any way you could. Men will come to you and say "Why isn't there no effing Play Station in the association room? I know my rights. I know my human rights. Get me an effing Play Station." (RS11)

In the same vein, staff criticized men as men, complaining that they did not clean up after themselves and took little care of their surroundings. In such examples 
the male detainees were judged particularly harshly relative to the previous female occupants.

'Ninety percent of the girls, or ninety-nine percent of the girls clean. There was no graffiti, the grass was you know cut, the flowers were out. Sounds all silly little things, but that's the differences that you notice, you know what I mean.' (RS3)

The specific trajectory of Morton Hall as a former woman's prison shaped the everyday interactions of the staff and detainees, highlighting the salience of gender. In the transition to the IRC, the role of staff and their sense of self changed as they encountered an immigration system they found difficult to understand and a new population whom they struggled to recognize. For those officers who had worked in Morton Hall when it housed women, the loss of ties with the female prisoners was keenly felt. Gender, in this view, acted as both a source of recognition, and for some, a barrier to it.

\section{Recognition, Justice and Sovereign Power}

The one extant study of staff in an IRC, by political scientist Alexandra Hall (2010; 2012), considers these places through the combined lens of Michel Foucault and Giorgio Agamben, as, on the one hand, sites of sovereign power and on the other, of exception. Hall found staff to be fearful of the detainees and contemptuous of their obtruding claims. Detainees appeared to be frustrated and angry. Only very occasionally, were the officers able 'to recognize the detainees - 
far from being wholly other, dangerous, threatening - as just like them (and vice versa)' (Hall, 2010: 894, original italics).

Rather than viewing IRCs as places of exception we suggest they may be better understood as representative of the increasing insecurity inherent in an era of mass mobility. As others have observed, the Agamben (1998; 2005) framework obscures lived complexities and the connections between these sites and society more broadly (Butler, 2004; Rygiel, 2011). In contrast, the concept of recognition draws out these parallels through close attention to the varied lived insecurities and status deprivations of detention as these relate to what both detainees and staff believe they can legitimately claim. The accounts in this paper of the detainees and staff demonstrate how life in IRCs is forged through everyday, affective interactions, in which people recognize, misrecognize, deny and accept one another as fellow human beings with legitimate claims to social status. The legitimacy of such claims rests upon appeals to culturally and socially defined standards generated within the society in which the IRC is embedded. IRCs, this approach reveals, are tied to existing modes of cultural recognition and familiar structures of inequality. As such, analysis of these institutions can inform and draw upon wider political debates about belonging, justice and power in a global world.

Separated from family and friends, detainees must either find solace and self-determination within themselves or through their interactions with staff and other detainees. Yet, in the confused environment of the IRC, misrecognition of some detainees by staff, as representatives of the state, can subtly highlight the status insecurity of the detainees at a higher level in their relationship to the state, their claims to citizenship and their cultural belonging to the UK. 
Concentrating on recognition and misrecognition in such an environment reveals a close relationship between power and affect.

In IRCs such matters are framed by the institutional lack of clarity over the purpose and effect of detention. Sometimes, staff and detainees found that their shared confusion was a source of recognition in its own right, as this staff member commented sympathetically:

'[T]he country is in a complete and utter mess, right...And we're keeping them here, the massive cost...They're sick of being stuck in this place. And I really do sympathise with them.' (RS11)

All too often, however, staff and detainees retreat into separate camps, unable to find points of commonality. As one detainee 0., originally from Kenya, put it:

[T]here is a rift, there is a big rift at the moment. There is a rift between, between the detainees and the officers. Or anybody who wears a key.... And a lot of it is because ... detainees and officers are not linking up.' (R23)

While many detainees desire and fight for recognition from custody staff, those who hold the power to grant legal recognition are elsewhere, in UKBA offices, visible just beyond the inner compound fence, or in central government buildings hundreds of miles away. For staff too, decisions about their official status are taken offsite. As these processes work their course separately from the participation of those inside the IRC, everyday interactions for both staff and 
detainees become a substitute arena for making status claims and searching for recognition. Yet, this arena is one populated by those who either fail to or cannot acknowledge or 'link up' with these claims. This is clearly a source of pain and frustration for many. It can also engender resistance; IRCs are volatile places where disturbances and escapes are not uncommon. Misrecognition then, is here both a cause of institutional uncertainty and its effect.

\section{Conclusion}

As institutions that manifest the state's unsure and anxious attempt to reassert sovereign control over territory and people, IRCs present challenges and insights into studying and understanding penal power in an era of mass mobility. Unlike prisons, which they so closely resemble, detention centres do not produce recognizable subjects. Whereas the goal and originating purpose of prison is to 'make sense of' (punish, reform, deter) offenders, IRCs seem designed to have the opposite effect, rendering those within unfamiliar. Detainees, their confinement attests, are not like 'us'. They are foreign, bound for and belonging elsewhere. Their foreignness cannot be changed, no matter how long they have lived in Britain. They are always, already, different and unknowable, potentially a threat.

At the same time, however, removal centres are neither 'states of exception,' nor are detainees abject and entirely powerless. Notwithstanding their undeniably vulnerable status, many resist their detention and seek legal remedy. Some have considerable ties to the UK, which, under the Human Rights Act may suffice as grounds to remain. Others fail to produce travel documents, file judicial reviews, or refuse to get on the plane. Such strategies are time limited in effect and individually extremely distressing and demeaning. However, they 
have some success, as national statistics reveal that one third of the detained population is bailed or temporarily admitted each year to the British community. Detention may be easy to implement, deportations and removals, however, are difficult to enforce (Gibney, 2008).

In creating institutions where identity justifies and defines custody, the state has set itself an impossible task. Under conditions of globalization and mass migration, it is increasingly difficult to identify who among us 'belongs' or is entitled to stay. Considerable work in this regard has been created by housing detainees in institutions that look like prisons, since the stigma of such places attaches to them, reinforcing ideas of their dangerousness and threat. However, the appeal to the prison itself creates other problems as staff and detainees continually compare the two institutions and find IRCs lacking.

It would be naïve to suggest that detainees are able to succeed in their bids for recognition. Immigration laws continue to tighten. What these places reveal, however, is the link between penal power and identity. As this article has suggested, familiar beliefs about gender percolate through IRCs, intersecting with other tropes about race, class, and citizenship. In myriad everyday ways, staff and detainees grapple with such matters, as they sometimes recognize and other times deny one another. The institutional uncertainty of IRCs is extreme, and may, in time, reduce. However, as our social world is shaped increasingly by interactions with those who are both like and not like us, it is time that criminologists put the relationship between power and identity at the heart of their analysis. 


\section{References}

Aas, K. and M. Bosworth. (Eds.). (2013). Migration and Punishment: Citizenship, Crime Control, and Social Exclusion. Oxford: Oxford University Press.

Agamben, G. (2005) State of Exception. Chicago: University of Chicago Press.

Agamben, G. (1998). Homo Sacer: Sovereign Power and Bare Life. Stanford, CA: Stanford University Press.

Bosworth, M. (2014). Inside Immigration Detention: Foreigners in a Carceral Age. Oxford: Oxford University Press.

Bosworth, M. (2013) 'Can Immigration Detention be Legitimate?' in K. F. Aas and M. Bosworth (Eds.). Migration and Punishment: Citizenship, Crime Control, and Social Exclusion. Oxford: Oxford University Press.

Bosworth, M. (2012). 'Subjectivity and identity in detention: Punishment and society in a Global Age.' Theoretical Criminology. 16(3): 123 - 140.

Bosworth, M., and B. Kellezi, (2013). 'Developing a Measure of the Quality of Life in Immigration Detention.' Prison Service Journal. 205: 10 - 15.

Braggins, J., and Talbot, J. (2004). Wings of Learning: The role of the prison officer in supporting prisoner education. The Centre for Crime and Justice Studies Available at http://esmeefairbairn.org.uk/news-andlearning/publications/wings-of-learning-the-role-of-the-prison-officer-insupporting-prisoner-edu. Accessed 22 February, 2013.

Butler, J. (2004). Precarious Life: The Powers of Mourning and Violence. London: Verso.

Crewe, B. (2009). The Prisoner Society: Power, Adaptation and Social Life in an English Prison. Oxford: Oxford University Press. 
Fili, A. (2013). 'The Maze of Immigration Detention in Greece: A Case study of the Athens Airport Detention Facility.' Prison Service Journal. 205: 34 - 38.

Fraser, N. (1997). Justice Interruptus: Critical Reflections on the "Postsocialist" Condition. New York: Routledge.

Fraser, N. (2000). “Rethinking Recognition: Overcoming Displacement and Reification in Cultural Politics," New Left Review. 3: 107-120.

Fraser, N. (2003). Social Justice in the Age of Identity Politics: Redistribution, Recognition, and Participation. In N. Fraser and A. Honneth. Redistribution or Recognition? A Political- Philosophical Exchange. London: Verso and Frankfurt: Suhrkamp.

Fraser, N. (2007). 'Feminist Politcs in the Age of Recogntion: A Two-Dimensional Approach to Gender Justice.' Studies in Social Justice. 1(1): 23 - 35.

Fraser, N., and Honneth, A. (2003). Redistribution or Recognition? A PoliticalPhilosophical Exchange. London: Verso and Frankfurt: Suhrkamp.

Gibney, M. (2008). Asylum and the Expansion of Deportation in the United Kingdom. Government and Opposition. 43(2): 146 - 167.

Hall, A. (2010). '"These People Could be Anyone": Fear and Contempt (and Empathy) in a British Immigration Removal Centre.' Journal of Ethnic and Migration Studies. 36(6): 881 - 898.

Hall, A. (2012). Border Watch: Cultures of Immigration, Detention and Control. London: Pluto Press.

Honneth, A. (1996). The Struggle for Recognition: The Moral Grammar of Social Conflicts. Boston, MA: MIT Press.

House of Commons Justice Committee. (2009). Role of the Prison officer. London: The Stationery Office, Limited. HC 361. Available at: 
http://www.publications.parliament.uk/pa/cm200809/cmselect/cmjust/ 361/361.pdf. Accessed 22 February, 2013.

HMIP. (2012). Expectations: Criteria for Assessing the Conditions for and treatment of immigration detainees. London: HMIP. Available: http://www.justice.gov.uk/downloads/about/hmipris/immigrationexpectations.pdf. Accessed 8 March 2013.

Kaufman. E., and Bosworth, M. (2013). 'Prison and National Identity: Citizenship, Punishment and the Sovereign State.' In D. Scott. (Ed.). Why Prison? Cambridge: Cambridge University Press.

Kymlicka, W. and W.J. Norman (2000). Citizenship in Diverse Societies. Oxford: Oxford University Press.

McNay, L. (2008) "The Trouble with Recognition: Subjectivity, Suffering, and Agency." Sociological Theory 26(3): 271-296.

Liebling, A. assisted by Arnold, H. (2004). Prisons and their Moral Performance: A Study of Values, Quality and Prison Life. Oxford: Clarendon Studies in Criminology.

Liebling, A., Arnold, H., and Straub, C. (2011). An Exploration of Staff-Prisoner Relationships at HMP Whitemoor: 12 Years on (Revised Report). London: Ministry of Justice and Cambridge Institute of Criminology. Available at: http://www.justice.gov.uk/downloads/publications/research-andanalysis/moj-research/staff-prisoner-relations-whitemoor.pdfAccessed 22 February, 2013.

Liebling, A., and Price, D. (2001). The Prison Officer. Leyhill: Prison Service and Waterside Press. 
Liebling, A., Price, D. and. C. Elliot (1999). 'Appreciative Inquiry and Relationships in Prison.' Punishment \& Society. 1(1): 71 - 98.

Musinguzi, K. (2013). 45991. The Prison Service Journal. 205: 4 - 7.

Philips, C. (2012). The Multicultural Prison: Ethnicity, Masculinity, and Social Relations. Oxford: Oxford University Press.

Rygiel, K. (2011). "Bordering solidarities: Migrant activism and the politics of movement and camps at Calais", Citizenship Studies. 15(1): 1 - 19.

Taylor, C. (1994) 'The Politics of Recognition' in Taylor, Charles, and Amy Gutmann. Multiculturalism: (Expanded Paperback Edition). Princeton: Princeton University Press.

Young, I.M. (1990). Justice and the Politics of Difference. Princeton, NJ: Princeton University Press. 